\title{
Varibaculum cambriense
}

National Cancer Institute

\section{Source}

National Cancer Institute. Varibaculum cambriense. NCI Thesaurus. Code C86836.

A species of anaerobic, Gram positive, diptheroid bacteria assigned to the phylum

Actinobacteria. This species is catalase, lecithinase, lipase, and gelatinase negative. V.

cambriense has been isolated from human abscesses. 